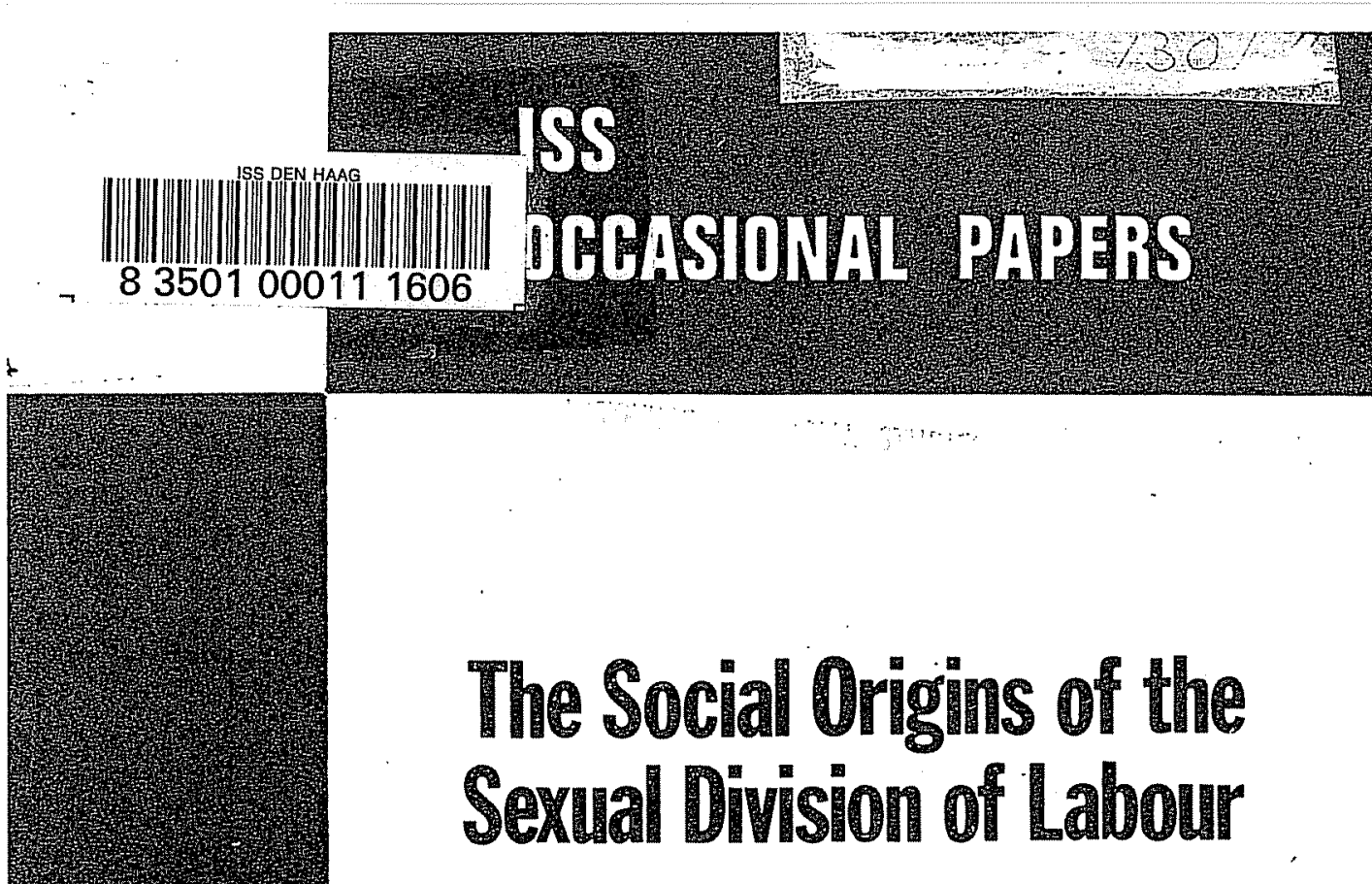

\title{
Maria Mies
}

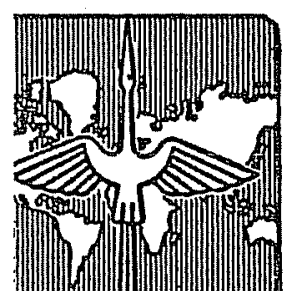

\section{NSTIUL OF SOCIAL STUDIES}

The hague 1 Te Nether ands 
a d a d a 

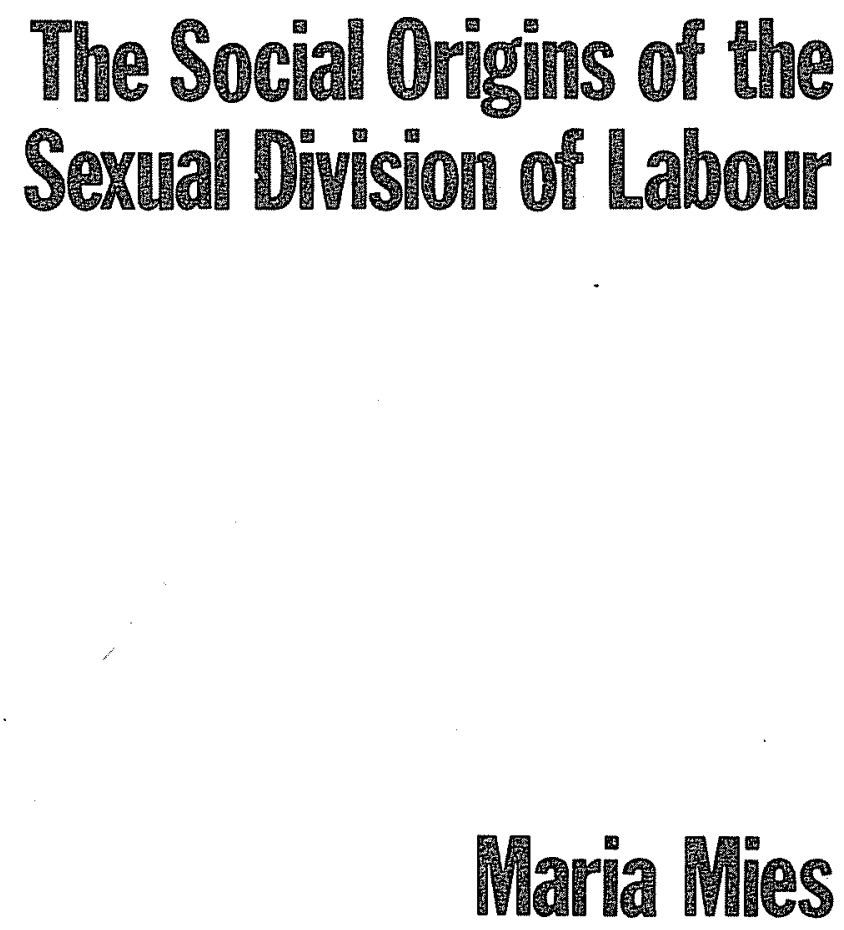

Senior Lecturer Institute of Social Studies No. 85, January 1981 

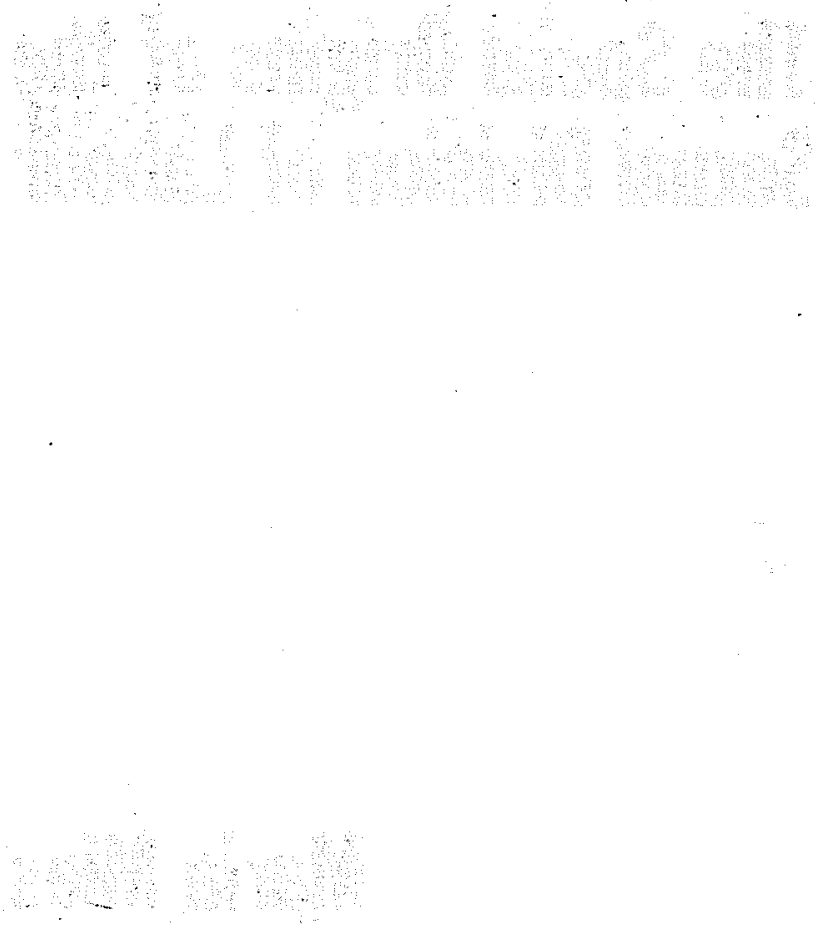


\section{THE SEARCH FOR ORIGINS WITHIN A FEMINIST PERSPECTIVE ${ }^{1}$}

Since the rise of positivism and functionalism as the dominant school of thought amongst western social scientists in the 1920s, the search for the origins of unequal and hierarchical relationships in society in general, and the asymmetric division of labour between men and women in particular, has been tabooed. The neglect and even systematic suppression of this question has been part of an overall campaign against Marxist thinking and theorising in the academic world, particularly the AngloSaxon world (Martin and Voorhies 1975: 155ff). It is only now that this question is again being asked. Significantly, it was not first asked by academics, but by women who were actively involved in the women's struggle for emancipation. Whatever the ideological differences between the various feminist groups, they are united in their rebellion against this hierarchical relationship, which is no longer accepted as a biological destiny but is seen as something to be abolished. Their search for the social foundations of this sexual inequality and asymetry is the necessary consequence of their rebellion. Women who are committed to struggle against the age-old oppression and exploitation of women cannot rest content with the indifferent conclusion forwarded by many academics, i.e. that the question of origins should not be raised because we know so little about them. The search for the social origins of this relationship is part of the political strategy of women's emancipation (Reiter 1977). Without understanding the foundation and the functioning of the asymmetric relationship between men and women it is not possible to overcome it.

This political and strategic motivation fundamentally differentiates this new quest for the origins from other 
academic speculations and research endeavours. Its aim is not merely to analyse or to find an interpretation of an old problem, but rather to solve it.

The following discussion should therefore be understood as a contribution to 'spreading the consciousness of the existence of gender hierarchy and collective action aimed at. dismantling it' (Ibidem:5).

\section{PROBLEMS OF BIASED CONCEPTS}

When women began to ask about the origins of the unequal relationship between the sexes they soon discovered that none of the explanations that have been forwarded by social scientists since the last century were satisfactory.

In all explanations, whether they stem from an evolutionist, a positivist-functionalist, or even a Marxist approach, the problem that needs explanation is, in the last analysis, seen as biologically determined and hence beyond the scope of social change. Before discussing the origins of an asymmetric division of labour between the sexes, therefore, it is useful to identify the biologistic biases in some of the concepts commonly used in our debates.

This covert or overt biological determinism, paraphrased in Freud's statement that anatomy is destiny. is perhaps the most deeprooted obstacle to the analysis
of the causes of women's oppression and exploitation. Although women who struggle for their emancipation have rejected biological determinism, they find it very difficult to establish that the unequal, hierarchical and exploitative relationship between men and women is caused by social, i.e. historical, factors. One of their main problems is that not only the analysis as such but also the tools of the analysis, the basic concepts and definitions, are affected or rather infected by biological determinism. 
This is largely true of the basic concepts which are central to our analysis, such as that of nature, of Zabour, of the sexual division of Zabour, of, the family and of productivity. If these concepts are used without a critique of their implicit ideological biases, they tend to obscure rather than clarify the issues. This is above all true for the concept of nature.

Too often this concept has been used to explain social inequalities or exploitative relations as inborn and, hence, beyond the scope of social change. Women in particular should be suspicious when this term is used to explain their status in society. Their share in the production and reproduction of life is usually defined as a function of their biology or 'nature'. Thus, women's household and child-care work are seen as an extension of their physiology, of the fact that they give birth to children, of the fact that nature has provided them with a uterus. All the labour that goes into the production of life, including the labour of giving birth to a child, is not seen as the conscious interaction of a human being with nature, i.e. a truly human activity, but rather as an activity of nature, which produces plants and animals unconsciously and has no control over this process. This definition of women's interaction with nature - including her own nature - as an act of nature has had and still has far-reaching consequences.

what is, mystified by a biologistically determined concept of nature is a relationship of dominance and exploitation, dominance of the (male) human being over (female) nature. This dominance relationship is also implicit in the other concepts mentioned above when applied to women. Take the concept of labour! Due to the biologistic definition of women's interaction with nature, her work both in giving birth and raising children as well as the rest of domestic work, does not appear as work or labour. The concept of labour is usually reserved for men's productive work under capitalist 
conditions, i.e. work for the production of surplus value.

Although women also perform such surplus-valuegenerating labour, under capitalism the concept of labour is generally used with a male bias because women are typically defined as housewives, i.e. as non-workers.

The instruments of this labour, or the bodily means of production implicitly referred to in this concept, are the hands and the head, but never the womb or the breasts of a woman. Thus, not only are men and women differently defined in their interaction with nature but the human body itself is divided into truly 'human' parts (head and hand) and 'natural' or purely 'animal' parts (genitalia, womb, etc.).

This division cannot be attributed to a universal sexism of the men as such, but is a consequence of the capitalist mode of production which is only interested in those parts of the human body which can be directly used as instruments of labour or which can become an extension of the machine.

The same hidden asymmetry and biologistic bias, which could be observed in the concept of labour, also prevails in the concept of the sexual division of labour. Though overtly this concept seems to suggest that men and women simply divide different tasks among themselves, it hides the fact that men's tasks are usually considered as truly human ones (i.e. conscious, rational, planned, productive, etc.), whereas women's tasks are, again seen as basically determined by their 'nature'. The sexual division of labour, according to this definition, could be paraphrased as one between 'human labour' and 'natural' activity. This concept obscures the fact, however, that the relationship between male (i.e. 'human') and female ('natural') labourers or workers is a relationship of dominance and. even of exploitation. 2

Yet, when we try to analyse the social origins of this division of labour, we have to make clear that we 
mean this asymmetric, hierarchical and exploitative relationship and not a simple division of tasks between equal partners.

The same obfuscating logic prevails with regard to the concept of family.. Not only is this concept used and universalised in a rather euro-centric way, presenting the nuclear family as the basic and timeless structure of the institutionalisation of men-women relationships, it also hides the fact that the structure of this institution is an hierarchical, non-egalitarian one. Phrases like 'partnership within the family' only serve to veil the true nature of the institution.

This brief discussion of the biologistic biases inherent in some of the important concepts shows: that the ideological function of these biases should be systematically exposed, i.e. their function to obscure and mystify asymmetric and exploitative social relations.

With regard to the problem before us, namely, analysis of the social origins of the sexual division of labour, this means that we are not asking: when did a division of labour arise between men and women? (Such a division is the necessary consequence of all human interaction with nature.) Our question is rather: why did this division of labour become a relationship of dominance and exploitation, why did it become an asymmetric, hierarchical relationship? This question still looms over all discussions of women's liberation.

\section{SUGGESTED APPROACH}

(a) What can we do to eliminate the biases in the abovementioned concepts? Not use them at all, as some women suggest? But then we would be without a language in which to express our ideas. Or should we invent new ones? This is what others feel is better. But concepts summarize historical practice and theory and cannot voluntaristically be invented. We have to accept that the basic 
concepts used in our analysis have already been 'occupied' - like territories or colonies - by dominant sexist ideology. Though we cannot abandon them, we can look at them 'from below', not from the point of view of the dominant ideology but from that of the historical experiences of the oppressed, exploited and subordinated, and their struggle for emancipation:

It is thus necessary, with regard to the concept of productivity of labour, to reject its narrow definition and to show that labour can only be productive in the sense of producing surplus value as long as it can tap, extract, exploit, and appropriate that labour which is spent in the production of $2 i f e$, or in subsistence production which is non-wage labour mainly done by women. As this production of life is the perennial precondition of all other historical forms of productive labour, including that under conditions of capital accumulation, it has to be defined as work and not as unconscious 'natural' activity. Human beings do not only live: they produce their life.

In what follows, I shall call the labour that goes into the production of life productive labour. The separation from, and the superimposition of, surplus-producing labour over life-producing labour is an abstraction which leads to the fact that women and their work are being 'defined into nature'.

(b) The search for the origins of the hierarchical sexual division of labour should not be limited to the search for the moment in history or pre-history when the 'worldhistoric defeat of the female sex' (Engels) took place. Though studies in primatology, pre-history and archaeology are useful and necessary for our search, we cannot expect them to provide an answer to this question unless we are able to develop non-biologistic concepts of men and women and their relations to nature and history.

As Roswitha Leukert puts it: 'The beginning of human history is primarily not a problem of fixing a certain 
date, but rather that of finding a materialist concept of man [the human being_7 and history' (Leukert 1976: 18, $\operatorname{trans1.} \mathrm{MM})$.

If we use this approach, which is closely linked to the strategic motivation mentioned earlier, we shall see that the development of vertical, unequal relationships between womar and man is not only a matter of the past.

We can learn a great deal about the actual formation of sex hierarchies if we look at 'history in the making'; i.e. if we study what is happening to women under the impact of capitalism both in its centres and in its periphery, where poor peasant and tribal societies are now being 'integrated' into a so-called new national and international division of labour under the dictates of capital accumulation. Both in the capitalist centres and in the peripheries a distinct sexist policy was and is used to subsume whole societies and classes under the dominant capitalist production relations.

(This strategy usually appears in the guise of 'progressive' or liberal family laws (e.g. the prohibition of polygamy), family planning and development policies. The demand to 'integrate women into development', first voiced at the International Women's conference in Mexico (1975), is largely used in Third world countries to recruit women as the cheapest, most docile and manipulable labour force for capitalist production processes, both in agro-business and industry as well as in the unorganised sector (Froblel, Kreye, Heinrichs 1977). ${ }^{3}$

This also means that we should no longer look at the sexual division of labour as a problem related to' the family, but rather as a structural problem of a whole. society. The hierarchical division of labour between men and women and its dynamics form an integral part of dominant production relations, i.e. class relations of a. particular epoch and society and of the broader national and international divisions of labour. 


\subsection{Appropriation of Nature by Women and Men}

To search for a materialist concept of men/women and history, however, means to search for the human nature of men and women. But human nature is not a given fact. It evolved in history and cannot be reduced to its biological aspects: the physiological dimension of human nature is always linked to its social dimension. Therefore, human nature cannot be understood if we separate its physiology from its history: Human nature does not evolve out of biology in a linear, monocausal process, but is the result of the history of the interaction of men/women with nature and with each other. Human beings do not simply live, animals live. Human beings produce their lives. This production takes place in a historical process.

In contrast to the evolution in the animal world (natural history), human history is social history right from the beginning. All human history is characterized; according to Marx and Engels, by 'three moments' which existed at the beginning of mankind and still exist today: (1) people must live in order to be able to make history, they must produce the means to satisfy their needs: food, clothing, a shelter; (2) the satisfaction of needs leads to new needs, they develop new instruments to satisfy their needs; and (3) men who reproduce their daily life must make other men, must procreate - the relationship between men and women. Marx characterizes this 'production of life' as a process of 'appropriation of nature' through sensuous, objective activity (Marx/ Engels 1970).

Later, Marx uses the expression 'appropriation of the natural matter' to conceptualize 'work' in its broadest sense: work, as appropriation of nature for the satisfaction of human needs:

Laboux is, in the first place, a process in which both man and nature participate, and in which man on his own accord starts, regulates; controls the material re-actions 
between himself and nature. He opposes himself to nature as one of her own forces, setting in motion arms and legs, head and hands, the natural forces of his body, in order to appropriate Nature's productions in a form adapted to his wants. By thus acting on the external world and changing it, he at the same time changes his own nature (Marx 1974: 173).4

We must stress that this 'appropriation of nature' is the characteristic of all human history, including its earliest, primitive stages. Engels separates these earliest stages as pre-history, from the actual human history which, according to him, began only with civilization, i.e. with fullfledged class and patriarchal relations. Engels is not able to answer the question. of how humanity then jumped from pre-history to social history; moreover, he does not apply the method of dialectical historical materialism to the study of these primitive societies which have 'not yet entered history'. He thinks that the laws of evolution prevailed up to the emergence of private property, of family and the state (Engels 1973).

But if we want to find a materialist concept of women and men and their history we have first to analyse their respective interaction with nature and how, in. this process, they built up their own human or social nature. If we were to follow Engels, we would have to relegate women's interaction with nature to the sphere of evolution. (This, in fact; is being done by functionalists and behaviourists all over the world.) We would have to conclude that women have not yet entered history (as defined by men) and still basically belong to the animal world: History, for Engels, begins with civilization, the exploitation of woman by man and man by man:

\subsection{The Appropriation of their own Bodies by Women/Men}

The labour process, in its elementary form, according to Marx, is a conscious action with a view to producing use-values. In a wider sense, it is the appropriation 
of natural substances for human requirements'. This 'exchange of matter' (Stoffwechsel) between human beings and nature is the everlasting nature-imposed condition of human existence, or rather is common to every historical phase (Marx 1974: 179). In this 'exchange of matter' between human beings and nature, the former, both women and men, not only develop and change the external nature with which they: find themselves confronted, but also their own bodily nature.

The interaction between human beings and nature for the production of their human requirements, like all production, needs an instrument or means of production.

The first means of production with which human beings act upon nature is their own body. It is also the eternal precondition of all further meanis of production. But: the body is not only the 'tool' with which human beings. act upon nature; it is also the goal of the satisfaction of needs. Human beings not only use their bodies to produce use-values; they keep their bodies alive - in the widest sense - by the consumption of their products.

In his analysis of the labour process in its widest sense as appropriation of natural substances, Marx does not differ between men and women. For our subject, however, it must be stressed that men and women act upon nature with a qualitatively different body. If we want to achieve clarity about the asymmetric division of labour between the sexes, it is necessary to talk not of MAN's (the abstract generic being) appropriation of nature, but of women's and men's appropriation of nature. This is based on the assumption that there is a difference in the ways in which women and men appropriate nature. This difference is usually obscured because 'humanness' is identified with 'maleness'. 5

Male-ness and female-ness are not biological givens, but rather the result of a long historical process. In each historic epoch male-ness and female-ness are differently defined, the definition depending on the principal 
mode of production in those epochs. This means that the organic differences between women and men are differently interpreted and valued, according to the dominant form of appropriation of natural matter for the satisfaction of human needs. Therefore, men and women develop a qualitatively different relationship to their own bodies. Thus in matristic ${ }^{6}$ societies, "female-ness was interpreted as the social paradigm of all productivity, as the main active principle in the production of life. ${ }^{7}$ All women were defined as 'mothers'. But 'mothers' then had a different meaning. "Under capitalist conditions all women are socially defined as housewives (all men as breadwinners), and motherhood has become part and parcel $\rightarrow$ of this housewife-syndrome. The distinction between the earlier, matristic definition of female-ness and the modern one is that the latter has been emptied of all active, creative, productive (i.e. human) qualities. The historically developed qualitative difference in the appropriation of the male and female bodily nature has also led to 'two qualitatively different forms of appropriation of external nature, that is, two qualitatively distinct forms of relations to the objects of appropriation, the objects of sensuous bodily activity' (Leukert 1976: 41 ).8

\subsection{The Human's objective Relationship to Nature (Gegenstandbeaug zur 'Natur)}

It is first necessary to stress the difference between an animal's or a human's orientation to the object. The human orientation is one of praxis, i.e. action plus reflection. This becomes visible only in the historical process, and implies social interaction or cooperation. The human body was not only the first means of production, but was also the first force of production. In other words, the human body is experienced as able to bring forth something new and, hence, to change the external environment and human nature. In contrast to that of the 
animals, the human's objective orientation to the environment is a productive one. In the appropriation of the body as a productive force, the difference between the woman and the man has had far-reaching consequences.

What characterises woman's objective relationship to nature, to her owm, as well as to the external environment? Woman obviously experiences her whole body as being productive, not only her head and hands. From her body she produces new children as well as the primary food for those children. It is crucial to our subject that woman's activity in producing children and milk is understood as truly human, i.e. a conscious, social activity. Women have appropriated their own nature, their capacity to give birth and to produce milk in the same way as men have appropriated their own boally nature, in the sense that their hands and head have acquired skills through work and reflection with which to make and handle tools. In this sense, the activity of women in bearing and rearing children has to be understood as work. It is one of the major obstacles to women's liberation, i.e. humanization, that these activities are still interpreted as purely physiological functions, comparable to those of other mamnals, and lying outside the sphere of conscious human influence. The view that the productivity of the female body is identical to animal fertility-a view which at present is propagated and popularized the world over by demographers and population planners - has to be understood as a result of the patriarchial and capitalist division of labour, and not as its precondition. 9

In the course of their history, women have observed the changes in their ow bodies and have acquired, through observation and experiment, a vast amount of experiential knowledge about the functions of their bodies, about the rhythms of menstruation, about pregnancy and childbirth. This appropriation of their own bodily nature was closely related to the acquisition of knowledge about the generative forces of external nature, about plants, animals, the earth, water and air. 
Thus, women did not simply breed children like cows, but appropriated their own generative and productive forces; they analysed and reflected upon their own and former experiences, and passed them on to their daughters." In other words, they were not helpless victims of the generative forces of their bodies but learned to influence them, including the number of childxen they wanted to have.

Today, we have sufficient evidence at our disposal to allow the conclusion that, in pre-patriarchial societies, women knew better how to regulate the number of their children and the frequency of their births than do modern women who have lost this knowledge due to their subjection to the civilizing process of the males.

Gatherers and hunters and other primitive groups sracticed; and still practice various methods by which to limit the number of births and children. Apart from infanticide, which was most probably the earliest method (Fisher 1978: 202), women in many societies have used various plants and herbs as contraceptives or to induce abortions. The Ute Indians used litho-spermium, the Bororo women in Brazil used a plant which made them temporarily sterile. The missionaries then persuaded the women not to use the plant (Fisher 1979: 204). Elizabeth Fisher tells us about methods used by women among the Australian aborigines, certain tribes in Oceania, and even in ancient Egypt, which were predecessors of modern contraceptives. Women in Egypt used a vaginal sponge dipped in honey to reduce the mobility of sperms. There was also the use of acacia tips which contained a spermicidal acid (Fisher 1979: 205).

Another method of birth control used widely among contemporary gatherers and hunters is a prolonged period of breastfeeding., Robert May reports on studies which prove that 'in almost all primitive gatherers and hunters' societies fertility is lower than in modern civilised societies. Through prolonged lactation, ovulation is 
reduced, leading to longer intervals between births'. May also observed that these women reached puberty at a much later age than civilised women. He attributes the much more balanced population growth which can be observed today among many tribes as Iong as they are not integrated into civilised society, to 'cultural practices which unconsciously contribute to a reduction of ferti1ity' (May 1978: 491). He criticises correctly those who think that the low rate of population growth in such societies is the result of a brutal struggle for survival; but nevertheless; he does not see this situation as being a. result of women's conscious appropriation of their generative forces. 10

Women's production of new life, of new women and men, is linked inseparably to the production of the means of subsistence for this new life. Mothers who give birth to children and who suckle them, necessarily have to provide food for themselves and for the children. Thus, the appropriation of their bodily nature, the fact that they produce children and milk, makes them the first providers of daily food, be it as gatherers, who simply collect what they find in nature - plants, small animals, fish, etc. - or as agriculturists. The first division of labour by sex, i.e. that between the gathering activities of the women and the sporadic hunting of the men, most probably originated in the fact that women necessarily were responsible for the daily subsistence. From the beginning, the gathering of plants, roots, fruits, mushrooms, nuts, small animals, etc., was a collective activity of women.

It may be assumed that the necessity to provide the daily food, and long experience with plants and plant life, eventually led to the regular cultivation of grain and tubers. According to Gordon Childe, this invention took place in the Neolithic Age, particularly in Eurasia, where wild grains were first cultivated. Childe and many other scholars attribute the introduction of cultivation to women, who also invented the first tools necessary for 
this new mode of production: the digging stick - which was already in use for digging out wild roots and tubers - and the hoe (Childe 1976, Reed 1975, Bornemann 1975, Thomson 1960, Chattopadhyaya 1973, Ehrenfels 1941, Briffault 1952).

The regular cultivation of food plants, mainly tubers and grains, signified a new stage and an enormous increase in the productivity of female labour which, according to many authors, made surplus production possible for the first time in history. Childe calls this transformation the 'neolithic revolution', which he attributes to the regular cultivation of grain. On the basis of recent archaeological findings in Iran and Turkey, however, Elizabeth Fisher argues that people had already been able to collect a surplus of wild grains and nuts in the gathering stage. The technological precondition for the collection of surplus was the invention of containers, baskets of leaves and plant fibres, and jars. It seems plausible that the technology of preservation preceded the new agricultural technology, and was equally necessary for the production of a surplus.

The difference between the two modes of production is therefore not so much the existence of a surplus, but rather that women developed the first truly productive relationship to nature. Gatherers still lived in a society of simple appropriation, but with the introduction of plant cultivation we can speak for the first time of a 'production society' (Sohn-Rethel 1970). Women not only collected and consumed what grew in nature, but they made things grow.

Women's objective-relationship to nature was not only a productive one; it was also, right from the beginning, social production. In contrast to grown men, who could gather and hunt only for themselves, women had to share their products at least with their young children. In other words, their specific objective relationship to nature (to their own bodily nature as well as to the 
external environment), namely, to be able to let grow and to make grow, made them the inventors of the first social relationships, those between mothers and children.

Many authors have come to the conclusion that mother-children groups were the first social units not only units of consumption but also units of production. Mothers and children worked together as gatherers and as early hoe-cultivators. Such authors are of the opinion that grown men were only temporarily and peripherally integrated or socialised into these early matricentric or matristic units: (Briffault 1952, Reed 1975, Thomson 1960).

Martin and Voorhies argue that matricentric units coincided with a vegetarian phase of hominid evolution. 'Adult males would maintain no permanent attachment to these mother-child units - except to the unit of their birth' (Martin and Voorhies 1975: 174). The permanent integration of males into these units therefore has to be seen as a result of social history. The productive forces that developed in these first social units were not only technological in nature, but increased also and above all, the capacity for human co-operation. The ability 'to plan for tomorrow', to anticipate the future, to learn from one another, to pass this knowledge on from one generation to the next and to learn from past experiences; in other words, to constitute history.

Women's objective relationship to nature, as this developed over time, can be sumarised as follows:

(a) Their interaction with nature, with their own nature as well as the external environment, was a reciprocal process. They conceived of their own bodies as being productive in the same way as they conceived of external nature as being productive.

(b) Although they appropriate nature, this appropriation does not constitute a relationship of dominance or a property relation. Women are 
not owners of their own bodies or of the earth, but they co-operate with their bodies and with the earth in order 'to let grow and to make grow'.

(c) As producers of new life they also became the first subsistence producers and the inventors of the first productive economy, implying from the beginning social production and the creation of social relations, i.e. of society and history.

\subsection{Man's objective Relationship to Nature}

Man's objective relationship to nature, as that of woman, has both a material-bodily and an historical dimension. The material side of this relationship - which exists at all times as long as men and women live - means that men appropriate nature by means of a qualitatively different body than do women.

They cannot experience their own bodies as being productive in the way that women can. Male bodily productivity cannot appear as such without the mediation of external means, of tools, whereas woman's productivity can so appear. Men's contribution to the production of new life, though necessary at all times, became visible only after a long historical process of men's action on external nature by means of tools and their reflection on this process. Men's conception of their own bodily nature, the imagery they use to reflect upon themselves, is influenced by the different historic forms of interaction with external nature and the instruments used in this work-process. Thus, male self-conception as human, i.e. as being productive, is closely linked to the invention and control of tools. Without tools man is no MAN. In the course of history men's reflection of their objective relationship to external nature has found expression in the symbols with. which they have described their own body organs. It is interesting that the first 
male organ to gain prominence as the symbol. of male productivity was the phallus, not the hand, though the hand was the main instrument for tool-making. This must have happened at the stage when the plough replaced the digging stick or the hoe of early female cultivators. In some Indian languages there is an analogy between plough and penis. In Bengali-slang the penis is called 'the tool' (Yantra). This symbolism, of course, not only expresses an instrumental relationship to external nature, but also to women. The penis is the tool, the plough, the 'thing' with which man works upon woman. In North Indian languages the words for 'work' and 'coitus' are the same, namely, kam. This symbolism implies that women have become 'external nature' for men. They are the earth, the field, the furrow (sita) upon which men sow their seeds (semen).

But these analogies of penis and plough, seed and semen, field and women are not only linguistic expressions of an instrumental objective-relationship of men towards. nature and women. They also indicate that this objectiverelationship is already characterized by dominance. Women are already defined as part of the physical conditions of (male) production.

We do not know much about the historic struggles which took place before men's objective relationship to nature was able to establish itself as one of a superior productivity over that of women. But from the ideological battles that went on in ancient Indian literature for several centuries over the question of whether the nature of the 'product' (grain, children) was determined by the field (woman) or by the seed (man), we get the idea that the subordination of female productivity to male productivity was by no means a peaceful process, but was part and parcel of class struggles and of the establishment of patriarchal property relations over land, cattle and women (J. Karve 1965). 11

It would be revealing to study the analogies between the sexual organs and the tools which man have invented 
in different historical epochs and for different modes of production. It is not accidental that in our time men call their penis a 'screwdriver' (they 'screw' a woman), a 'hammer', a 'file', a 'gun', etc. In the harbour of Rotterdam, a trading port, male sexual organs are called 'the trade'. This terminology tells us a great deal about how men define their relationship to nature, but also to women and to their own bodies. It is an indication of the close link in the minds of men between their work-instruments and their labour process and the self-conception of their own bodies.

Yet before men could conceive of their own bodies as being more productive than those of women, and could also in reality establish a relationship of dominance over women and external nature, they had first to develop a type of productivity which at least appeared independent of, and superior to, women's productivity. As we have seen, the appearance of men's productivity was closely linked to the invention of tools. Yet men could develop a productivity (apparently) independent of women's only on the basis of developed female productivity.

\section{FEMALE PRODUCTIVITY, THE PRECONDITION OF MALE PRODUCTIVITY}

If we keep in mind that 'productivity' means the specific capacity of human beings to produce and reproduce life in a historic process (see pp. 5-6) then we can formulate for our further analysis the thesis that female productivity is the precondition of male productivity and of all further world historic development. This statement has a timeless material dimension as well as an historical one.

The material dimension consists in the fact that women at alt times will be the producers of new women and men, and that without this production all other forms and modes of production lose their meaning. This sounds trivial, but it reminds us of the goal of all human 
history. The historical dimension lies in the fact that the various forms of productivity which men have developed in the course of history could not have emerged if they had not used and subordinated the various historic forms of female productivity.

In the following, this thesis will be used as a guiding principle in analysing the asymmetric aivision of labour between the sexes during some of the major phases of human history. This will help us to keep our feet on the ground and thus to de-mystify some of the common myths which are forwarded in explanation of the social inequality between women and men as being given by nature.

\subsection{The Myth of Man-the-Bunter}

Women's productivity is the precondition of all other human productivity, not only in the sense that they are always the producers of new men and women, but also in the sense that the first social division of labour, that between female gatherers (later also cultivators) and predominantly male hunters, could take place only on the basis of a developed female productivity.

Female productivity consisted above all in the abilicy to provide the daily subsistence, the guaranty of survival, for the members of the clan or band. Women had to secure the 'daily bread' necessary' not only for themselves and their children, but also for the men if they had no luck on their hunting expeditions, because hunting is an 'economy of risk'.

It has been proved particularly by the critical research of feminist scholars, that the survival of mankind has been due much more to 'woman-the-gatherex' than to 'manthe-hunter', in contrast to what is preached by socialDarwinists of old or new. Even among existing hunters and gatherers women provide up to $80 \%$ of the daily food, whereas men contribute only a small portion by hunting (Lee and de vore 1976, quoted by Fisher 1979: 48). By a 
secondary analysis of a sample of hunters and gatherers from Murdock's Ethnographic Atlas, Martin and Voorhies have proven that 58 of the subsistence of these societies was provided by gathering, $25 \%$ by hunting, and the rest by hunting and gathering together (1975: 181). Tiwi women in Australia, who are both hunters and gatherers, got 508 of their food by gathering, $30 \%$ by hunting and 20 o by fishing. Jane Goodale, who studied the Tiwi women, said that bush hunting and collecting was the most important productive activity: '... the women not only could. but did provide the major daily supply of a variety of foods to members of their camp... Men's hunting required considerable skill and strength, but the birds, bats, fish, crocodiles; dugongs and turtles they contributed to the household were luxury. items rather than staples" (Goodale 1971: 169).

It is obvious from these examples that among hunters and gatherers hunting by no means has the economic importance that is usually ascribed to it, and that women are the providers of the bulk of the daily staple food. In fact all hunters of big game, when they want to go on a hunting expedition, depend on the supply of food by their women which is not produced by hunting. This is why the old Iroquois women had a voice in decision-making on war and hunting expeditions. If they refused to give the men the necessary supply of food for their adventures, the men had to stay at home (Leacock 1978: 19, Brown 1970).

Elizabeth Fisher gives us further examples of foraging peoples among whom women are the main providers of the daily food, particularly in the temperate and southern zones. But she also argues that the gathering of vegetable food was more important for our early ancestors than hunting. She refers to the study of coprolites, fossile excrements, which reveals that groups who lived 200,000 years ago on the French Riviera, mainly survived on a diet of shellfish, mussels and grains, but not of meat. 12,000-year old coprolites from Mexico suggest that 
millets were the main staple food in that area (Fisher 1979: $57-58$ ).

Although it is obvious from these examples, as well as from common sense, that humanity would not have survived if man-the-hunter's productivity had been the base for the daily subsistence of early societies, the notion that man-the-hunter was the inventor of the first tools, the provider of food, inventor of human society, protector of women and children, persists not only in popular literature and films, but also among serious social scientists, also among Marxist scholars. ${ }^{12}$

The man-the-hunter hypothesis has been popularised, particularly by anthropologists and behaviourists who follow the line of thinking developed, by Raymond Dart, a South African anthropologist, who maintained that the first hominids had made their first tools out of the bones of killed members of their own kind (Fisher: 49-50). Following the hypothesis Konrad Lorenz (1963), Robert Ardrey (1966, 1976), Iionel Tiger and Robin Fox (1976) have argued that hunting had been the motor of human development and that the existing relationship of dominance between women and men originated in the 'biological infrastructure' of stone-age hunters (Tiger and Fox 1976). According to these authors, the (male) hunter was not only the inventor of the first tools (which of course were weapons), but also of the upright gait, because manthe-hunter needed to have his hands free for the throwing of projectiles. According to them, he is also the 'breadwinner', the protector of weak and dependent women, the social engineer, the inventor of norms and hierarchical systems which have only one aim, namely, to curb the biologically-programmed aggressiveness of the males in their fight for control over the sexuality of the females. They draw a direct line from the observed behaviour of some of the primates to the behaviour of the human male, and maintain that the male primates strive to reach the top of the male hierarchy in order to be able to subject 
the females for their own sexual satisfaction. 'The efforts of the human primate to get to the top of the male hierarchy, which apparently is only silghtly, but in fact fundamentally, different from that of the apes, aim at gaining control over the female members of his own group in order to exchange them against the women of another group [emphasis Tiger and Fox]. Thus he gets for himself sexual satisfaction and political advantages' (Tiger and Fox 1971):

The 'cultural' achievement of these human hunter primates seems to be that they have risen (or 'evolved') from the stage of rape to the stage of exchange of women. The exploitative dominance relationship between man and woman has been ingrained into the 'biological infrastructure' of the hunting behaviour: men are the providers of meat, for which women have a craving. Therefore, the hunters were able to subject and subordinate the women permanently as sexual objects and work-bees. What gave the hunters this tremendous advantage over women was, according to these authors, the 'bonding principle', which evolved out of hunting in groups. Tiger advanced the idea of the 'male bonding principle' as the root cause of male supremacy in his book Men in Groups in 1969, when the USA was in the midale of another adventure of man-the-hunter, the Vietnam war. Although Tiger knew, as Evelyn Reed points out, that meat-eating constituted only a tiny portion of the baboon diet, he claims that huring and meat-eating constitute the decisive factor in pre-human primate evolution and that male bonding patterns reflect and arise out of man's history as a hunter. 'so, in the hunting situation, it was the hunting group-male-plus-male-plus-male which ensured the survival of the entire productive community. Thus was the male-male bond as important for hunting purposes as the male-female bond was important for productive purposes, and this is the basis for the division of labour by sex' (Tiger 1969: $122,126)$. 
The man-the-hunter model as the paradigm of human evolution and development has been the basis of numerous scientific works on human affairs and has been popularised by the modern media. It has influenced the thinking of millions of people and is still constantly advanced to explain the causes of social inequality. Feminist scholars have challenged the validity of this model on the basis of their own research and that of others. They have unmasked it, including its basic premises of the male bonding principle, the importance of meat as food etc., as a sexist projection of modern, capitalist and imperialist social relations into pre-history and earlier history. This projection serves to legitimize existing relations of exploitation and dominance between men and women, classes and peoples, as universal, timeless and 'natural'. Evelyn Reed has rightly denounced the hidden fascist orientation behind the model, particularly in the writings of Tiger and his glorification of war (Reed 1978).

Although we are able to de-mystify the man-the-hunter hypothesis and to show that the great hunters would not have been able even to survive had it not been for the daily subsistence production of the women, we are still faced with the question why women, in spite of their superior economic productivity as gatherers and early agriculturists, were not able to prevent the establishment of an hierarchical and exploitative relationship between the sexes.

If we ask this question in this way, we assume that political power emerges automatically from economic power. The foregoing discussion has shown that such an assumption cannot be upheld, because male supremacy did not arise from man's superior economic contribution.

In the following. I shall try to answer this question by examining the various tools invented and used by women and men. 


\subsection{Women's Tools; Men's Tools}

The man-the-hunter model is in fact the latest version of man-the-toolmaker model, under which tools are above all weapons, tools to $\mathrm{kill}$.

The earliest tools of mankind, the stone axes and scrapers, were of an ambivalent character. They could be used to grind, smash and pulverize grains and other vegetable food and to dig out roots, but they could also be used to kill small animals, and we can assume that they were used by men and women for both purposes. The invention of arms proper, however, of projectiles, of the bow and arrow, is an indication that the killing of animals had become a major specialisation of one part of society, namely, men. The protagonists of the hunter hypothesis state that the first tools were invented by men. They ignore women's inventions connected with their subsistence production. As we have mentioned earlier, however, the first inventions were probably containers and baskets made of leaves, bark and fibres, and later jars. The digging stick and the hoe were the main tools for gathering as well as for early agriculture. Women must have continued with their technology while some men developed specialised hunting tools.

What is important here is that women's technology remained productive in the true sense of the word: they produced something new. Hunting technology, on the other hand, is not productive, i.e. hunting equipment proper cannot be used for any other productive activity - unlike the stone axe. Bows and arrows, and spears, are basically means of destruction. Their significance lies in the fact that not only can they be used to kill animals, but also to kill other human beings. It is this characteristic of the hunting tools which became decisive in the further development of male productivity as well as of unequal exploitative social relations, not the fact that hunters as providers of meat were able to raise the standards of nutrition of the community. 
Hence, we conclude that the significance of hunting does not lie in its economic productivity as such, as is wrongly assumed by many theoreticians, but in the particular objective-relationship to nature that it constitutes. That relationship of man-the-hunter is distinctly different from that of woman-the-gatherer or cultivator. Its characteristics are the following:

(a) The hunters' main tools are not instruments with which to produce life but to destroy it. Their tools are not basically means of production but of destruction, and can also be used as means of coercion against fellow human beings.

(b) This gives hunters a power over living beings, both animals and human beings, which does not arise out of their own productive work. They can appropriate not only fruits and plants (like the gatherers) and animals, but also other (female) producers by virtue of arms.

(c) The objective-relationship mediated through arms, therefore, is basically a predatory or exploitative one: hunters appropriate. life, but they cannot produce Iife. It is an antagonistic and non-reciprocal relationship. All later exploitative relations between production and appropriation are, in the last analysis, upheld by arms as means of coercion.

(d) The objective-relationship to nature mediated through arms constitutes a relationship of dominance and not of cooperation between hunter and nature. This relationship of dominance has become an integral element of all further production relations established by men. It has become, in fact, the main paradigm of their productivity. Without dominance and control over nature, men cannot conceive of themselves as being productive.

(e) 'Appropriation of natural substances' (Marx)' now also becomes a process of one-sided appropriation, of establishing property relations, not in the sense of humanization, but of exploitation of nature. 
(f) The use of arms meant that hunters were not only able to hurt animals but that they could also raid communities of other subsistence producers, kidnap their unarmed young and female workers, and appropriate them." It can be assumed that the first forms of private property were not cattle or other foods, but female staves who had been kidnapped (Meillassoux 1975, Bornemann 1975).

At this point it is important to point out that it is not the hunting technology as such that is responsible for the constitution of an exploitative dominancerelationship between man and nature, and between man and man, man and woman. Recent studies on hunting societies have shown that hunters do not have an aggressive relationship to the animals they hunt. The pygmies, for example, seem to be extremely peaceful people who know neither war nor quarrels nor witchcraft (Turnbull 1961). Also, their hunting expeditions are not aggressive affairs, but are accompanied by feelings of compassion for the animals they have to kill (Fisher 1979: 53).

The emergence of a specialised hunting technology; therefore, only implied the possibility of establishing relationships of dominance and exploitation. It seems that as long as the hunters remained confined to their limited hunting-gathering context they could not realise the exploitative potential of their predatory mode of production. Their economic contribution was not sufficient; they remained dependent for survival on their women's subsistence production.

\subsection{Pastoralists}

Though there may have been inequality between men and women, they were not able to establish a fullfledged dominance-system. The 'productive' forces of the hunters could fully be released only at the stage when pastoral nomads, who domesticated cattle and women, invaded agricultural communities. In other words, full realization. 
of the 'productive' capacity of this predatory mode of production presupposes the existence of other really productive modes, like agriculture.

Elizabeth Fisher considers that patriarchal relationships between men and women were established only after men had discovered their own generative capacities. This discovery, according to her, went hand-in-hand with the domestication and particularly the breeding of animals as a new mode of production. They discovered that one bull could impregnate many cows, and this may have led to the castration and elimination of weaker animals, The prime bull was then used at periods that the pastoral nomads considered to be the most appropriate for impregnating the cows. Female animals were subjected to sexual coercion. In other words, the free sexuality of wild animals was subjected to a coercive economy, based on breeding, with the object of increasing the herds. It is plausible that the establishment of harems, the kidnapping and raping of women, the establishment of patriarchal Iines of descent and inheritance, were part of this new mode of production. Women were subjected to the same economic logic and became part of movable property, like cattle.

This new mode of production was made possible by two things: the monopoly of men over arms, and long observation of the reproductive behaviour of animals. As men began to manipulate the reproductive behaviour of animals, they discovered their own generative functions. This led to a change in their relationship to nature as well as to a change in the sexual division of labour. For pastoral nomads, women are no longer very important as producers or gatherers of food, as is the case among hunters. They are needed as breeders of children, particularly of sons. Their productivity is now reduced to their 'fertility', which is appropriated and controlled by men (cf. Fisher 1979 : 248 ff). 
In contrast to the hunters' and gatherers' economy, which is mainly appropriative, the economy of the pastoral nomads is a 'productive economy' (Sohn-Rethel). It is obvious, however, that this mode of production presupposes the existence of means of coercion for the manipulation of animals and human beings and for the extension of territory.

\subsection{Agriculturalists}

It is therefore probably correct to say that the pastoral nomads were the fathers of all dominance relations, particularly that of men over women. But there are sufficient data available which suggest that exploitative men-women relationships existed among agriculturalists, not only after the introduction of the plough, as Esther Boserup believes (1975), but also among the hoe-cultivators in Africa, where even today farming is done mainly by women. Meillassoux (1: 1975) points out that in such societies, which he characterises as economies domestiques, the old men were in a position to establish a relationship of dominance over younger men and women because they could acquire more wives to work only for them. The marriage system was the mechanism by which they accumulated women and wealth, which in fact were closely related. Meillasoux, following Levi-strauss, takes the existence of an unequal system of exchange of women for granted and only in passing mentions the probable roots of this system, namely, the fact that due to the ongoing subsistence production of the women, the men were free to go from time-to-time on hunting expeditions: Hunting, for the men in these domestic economies, was a sporting and political rather than economic activity. On such expeditions, the men also kidnapped lonely gathering women and young men of other villages or tribes.

In a recent study on slavery in pre-colonial Africa, edited by Meillassoux numerous examples show that such 
hunters not only kidnapped and appropriated people whom they surprised in the jungle, but they also organised regular razzias into other villages to kidnap women. The women thus appropriated did not become members of the community, but were usually privately appropriated by the leader to the expedition, who would either use them as his slaves who had to work for him, or would sell them against bridewealth to other villages. These kidnapped women thus became a direct source for the accumulation of private property

slavery, hence, did not emerge from trade, but from the male monopoly over arms. Before slaves could be bought and sold they had to be captured, they had to be appropriated by a master, by force of arms. This predatory form of acquisition of labour power, both for work on 'private' plots and for sale, was considered the most 'productive' activity of these warrior-hunters who, that has to be kept in mind, were no longer hunters and gatherers, but Iived in an economic system based on women's productive agricultural work; they were the 'husbands' of female agriculturalists. Their productivity has been described by an old man of the Samos in upper volta as the productivity of bow and arrow, by which all other products - millets, beans, etc., and women - could be obtained:

our ancestors were born with their hoe, their axe, their bow and arrow. Without a bow you cannot work in the jungle. With the bow you acquire the honey, the peanuts, the beans, and then a woman, then children and finally you can buy domestic animals, goats, sheep, donkeys, horses. These were the riches of old. you worked with bow and arrow in the jungle, because there could be always someone who could surprise and kill you.

According to this old man there were 'commandos' of five or six men who would roam through the jungle trying to surprise and kidnap women and men who were alone. The kidnapped were sold (Heritier in Meillassoux 1975: 491). This clearly illustrates that the Samo men conceived of their own productivity in terms of arms, that they 
surprised lonely gatherers in the jungle in order to sell them. The reason for this was: what had been captured by surprise in the jungle was property (private property).: This private property was appropriated by the lineage of the hereditary chief (formerly the rainmakers' lineage), who then sold the captives to other lineages, either as wives against brideprice (in this case against Kauri-shells as money), or as slaves for agricultural work, or returned them against ransom money to their own village. These raids were thus a means for some men to accumulate wealth.

Female slaves were preferred and fetched a higher price because they were productive in two ways: they were agricultural workers, and they could produce more slaves. In these inter-village raids, the Samo usually killed the men because they were of no economic use to them. But women and children were captured, made slaves and sold.

Jean Bazin, who studied war and slavery among the Segu, calls the capture of slaves by warriors the 'most productive' activity of the men of this tribe.

The production of slaves is indeed a production .... in the whole of the predatory activity this is the only activity which is effectively productive, because pillage of goods is only a change of hands and place. The dominant moment of this production is the exercise of violence against the individual in order to cut her/him off from the local and social networks (age, sex, relatives, alliances, lineage, clientele, village) (Bazin in Meillassoux 2, 1975: 142).

On the basis of his studies among the Tuareg, Pierre Bonte draws the conclusion that slavery was the precondition for the expansion of the economies domestiques into a more diversified economy in which there is a great demand for labour. He sees slavery as the 'result and the means of unequal exchange! (Bonte in Meillassoux 2 , 1975: 54).

These examples from pre-colonial Africa make it clear that the predatory mode of production of men, based on the monopoly of arms, could become 'productive' only when 
some other, mostly female, production economies existed which could be raided. It could be characterised as non-productive production. They also show the close linkage between pillage, loot and robbery on the one hand, and trade on the other. What was traded and exchanged against money (Kauri shells) was not the surplus produced over and above the requirements of the community; what was robbed and appropriated by means of arms was, in fact, defined as 'surplus'.

In the last analysis we can attribute the asymmetric division of labour between women and men to this predatory mode of production, or rather appropriation, which is based on the male monopoly over means of coercion, i.e.: arms, and on direct violence by means of which permanent relations of exploitation and dominance between the sexes were created and maintained.

This non-productive, predatory mode of appropriation became the paradigm of all exploitative relations between human beings. Its main mechanism is to transform autonomous human producers into conditions of production for others, or to define them as 'natural resources' for others.

\section{6. 'MAN-THE-HUNTER' UNDER FEUDALISM AND CAPITALISM}

The full potential of the predatory mode could be realised only under feudalism and capitalism. The predatory mode of appropriation of producers, products and means of production by non-producers, was not abolished totally. when new and more peaceful modes of production replaced older ones. Rather, it was transformed and dialectically preserved, in the sense that it re-appeared under new forms of labour control.

Similarly, new forms of the sexual division of labour have so far not replaced the old forms but have only transformed them, according to the requirements of new modes of production. None of the modes of production. 
which came up later in history, did away with predation and the violent acquisition of producers, of means of production and products by non-producers. The later production-relations have the same basic structure of being asymmetric and exploitative. Only the forms of dominance and appropriation have changed. Thus, instead of using violent raids and slavery for acquiring more women as workers and producers than were born in a community, hypergamous marriage systems were evolved, which made sure that the BIG MEN could have access not only to more women of their own community or class, but also to the women of the small Men. Women became a commodity in an asymmetric or unequal marriage market, because control over more women meant accumulation of wealth (Meillassoux 1: 1975). $\therefore$ The BIG MEN then became the managers of social reproduction as well as of production. In all patriarchal civilisations the relationship between men and women maintained its character of being coercive and appropriative. The asymmetric division of labour by sex, once established by means of violence, was upheld by such institutions as the family and the state and also by means of powerful ideological systems, above all the patriarchal religions, which have defined women as part of nature which has to be controlled and dominated by man.

In this process, first women and later other exploited people and classes were defined as 'nature' by the dominant class, which defines itself as 'human':

The predatory mode of acquisition saw a renaissance. during the period of European feudalism. Feudalism as a specific mode of production based on ownership of land was built up with extensive use of violence and waxfare. In fact, the endogenous processes of class differentiation in peasant societies alone would not have given rise to feudalism, at least not in its European version which figures as the 'model' of feudalism. The predatory form of acquisition of new lands and the large-scale use of .... pillage and looting by the armed feudal class, formed an 
inseparable part of, and a precondition for, the rise and maintenance of this mode of production (Elias 1978, Wallerstein 1974).

Later, not only were new lands thus acquired, but with the lands the means or conditions of production the peasants - were also appropriated and tied to the feudal lord in a. specific production relation which did not allow them to move away from that land. They were seen as 'part' of the land. Thus, not only the women of these peasants, but the male peasants themselves were 'defined into nature', that is, for the feudal lord they had a status similar to that of women: their bodies no longer belonged to themselves, but to the lord, like the earth. This relationship is preserved exactly in the German term with which the serf is described, he is Leibeigener i.e. some one, whose body (Leib) is the property (Eigentum) of someone else. But, in spite of this changeover from direct violent acquisition of land and of the peasants who worked on it, to a 'peaceful' relation of structural violence, or, which is the same, to a dominance relationship between lord and serf, the feudal lords never gave up theix arms or their military power to expand and defend their lands and their wealth, not only against external enemies, but also against rebellions from within. This means that, even though there were 'peaceful' mechanisms of effective labour control, under feudalism these production relations were established and maintained through the monopoly over the means of coercion enjoyed by the dominant class. The social paradigm of man-the-hunter/warrior remained the basis and last resort of this mode of production.

The same can be said of capitalism. When capital accumulation became the dominant motor of productive activity in contrast to subsistence production, wage labour tended to become the dominant form of labour control.: Yet these 'peaceful' production relations, based on mechanisms of economic coercion (structural violence), could be built 
up only on the base of a tremendous expansion of the predatory mode of acquisition. Direct and violent acquisition of gold and silver and other products, mainly in Hispanic America; and of producers - first the Indians in Latin America and later African slaves - proved to be the most 'productive' activity in what has been described as the period of primitive accumulation.

Thus, capitalism did not do away with the former savage forms of control over human productive capacity, but rather reinforced and generalised them: 'Iarge-scale slavery or forced labour for the production of exchange value is prominently a capitalist institution, geared to the early pre-industrial stages of a capitalist world economy' (Wallerstein 1974: 88). This institution was also based on the monopoly of effective weapons and the existence of breeding grounds of enough 'human cattle' who could be hunted, appropriated, and subjugated. This involves a re-definition of the relation of man-the-hunter, now the rising European bourgeoisie, to nature and to women. Whereas under production-relations based on ownership of land, women and peasants were/are defined as 'earth' or parts of the earth, as nature is identified with the earth and her plants, under early capitalism slaves were defined as 'cattle' and women as 'breeders' of cattle. We have seen that pastoral nomads also defined women mainly as breeders, but what fundamentally distinguished the earlier pastoral patriarchs from the early capitalists was that the latter were not at all concerned with the reproduction of the labour force or the 'breeders' of this labour force. In the first instance, the capitalist is not a producer but an appropriator, who follows the paradigm of predatory acquisition, the precondition for unequal exchange. Whereas the ruling classes among the pastoralists and the feudal lords were still aware of their own dependence on nature, including women (whom they therefore tried to influence by magic and religion), the capitalist class saw itself from the beginning as 
lord and master over nature. Only now a concept of nature arose which generalised man-the-hunter's dominance relation to nature. The division of the world which followed, defined certain parts of the world as 'nature', i.e. as savage, uncontrolled, and therefore open for exploitation and the civilising efforts, and others as 'human', i.e. already controlled and domesticated. The early capitalists were only interested in the muscle-power of the slaves, their energy to work. . Nature for them was a reservoir of raw material, and the African women an apparently inexhaustible reserve of human energy.

The changeover from production relations based on a master-servant pattern to one of a contractual character between capital and wage labour, would not have been possible without the use of large-scale violence and the 'definition as exploitable nature' of vast areas of the globe and their inhabitants. This enabled the capitalists 'to take off' and to give concessions to the European workers out of the loot of the colonies and the exploitation of slaves.

In fact, one could say, to the same degree that the workers of the European centre states acquired their humanity, i.e. were 'humanized', the workers - men and women - of the peripheries, i.e. Eastern Europe and the colonies, were 'naturalized'.

The 'pacification' of European workers, the establishment of a new form of labour control through the wage nexus, the transformation of direct violence into structural violence, or of extra-economic coercion into economic coercion, however, needed not only special economic concessions but also political concessions.

These political concessions are not, as most people think, the male worker's participation in the democratic process, but his sharing the social paradigm of the ruling class, i.e. the hunter/warrior model. His 'colony' or 'nature', however, is not Africa, but the women of his own class. And within that part of nature, the boundaries 
of which are defined by marriage and family laws, he has the monopoly over the means of coercion, of direct violence, which, at the level of the state, the ruling classes have invested in their representatives, i.e. the king and later the elected representatives.

The process of 'naturalisation', however, affected not only the colonies as a whole and the. women of the working class, but also the women of the bourgeoisie were defined into nature as mere breeders and rearers of the heirs of the capitalist class. In contrast to the African women, who were part of the 'savage' nature, the bourgeois women were seen as 'domesticated' nature. 'Their sexuality, their generative powers, as well as all their productive autonomy, were suppressed and strictly controlled by the men of their class on whom they had become dependent for their Iivelihood. The domestication of the bourgeois women, their transformation into housewives, dependent on the income of the husband, became the model of the sexual division of labour under capitalism; it was also a political necessity, it was necessary for gaining control over the reproductive capacities of women, of $a z i$ women. The process of proletarianisation of the men was therefore accompanied by a process of 'housewifeisation! of women. In this process, the sphere in which labour power was reproduced, the house and the family, was 'defined into nature', but private, domesticated nature, and the factory became the place for public, social

(i.e. 'human') production.

Just as the process of 'naturalisation' of the colonies was based on large-scale use of direct violence and coercion, so also the process of domestication of European (and later of North American) women was not a peaceful and idyllic affair. Women did not voluntarily hand over control over their productivity, their sexuality and their generative capacities to their husbands and to the BIG MEN (Church, State). Only after centuries of most brutal attacks against their sexual and productive autonomy did 
European women become the dependent, domesticated housewives that they are in principle today.. The counterpart of the slave raids in Africa was the witchhunt in Europe. The two seem to be connected through the same dilemma which faces the capitalist version of man-the-hunter however much he may try to reduce women to a condition of production, to nature, to be appropriated and exploited, he cannot produce living human labour power without women. Arms give him the possibility of an exclusively male mode of production, namely, slavery (or war), which Meiliassoux considers to be the male equivalent of reproduction within a $\mathrm{kinship}$ system (Meillassoux 1978: 7), an effort of the men of a certain society to become independent of their women's reproduction. But this male mode of production has its natural limitations, particularly when the hunting grounds for human cattle become exhausted. It was necessary, therefore, to bring the generative and productive forces of European women under control. Between the 14 th and 18 th centuries, the male guilds and the rising urban bourgeoisie managed to push craftswomen out of the sphere of production (Rowbotham 1974, O'Faolain and Martines 1973). Moreover, for centuries, militions of women mostly of poor peasant or poor urban origin, were persecuted, tortured, and finally burnt as witches, because they tried to retain a certain autonomy over their bodies, particularly their generative forces. The attack of church and state on the witches aimed not only at the subordination of female sexuality as such, although this played a major role, but against their practices as abortionists and midwives. The feminist literature that has appeared in recent years gives ample evidence of this policy (Rowbotham 1974, Becker-Bovenschen-Brackert 1977, Dross 1978, Honegger 1979). Not only were women artisans pushed out of their jobs and their property confiscated by the city authorities, the state and the church, but women's control over the production of new life had to be smashed, 1 .e. 
their decision to give birth to a child or to abort. This war against women raged through Europe for at least three centuries (Becker-Bovenschen-Brackert 1977).

The witchhunt not only had the direct disciplinary effect of controlling women's sexual and reproductive behaviour, but also established the superiority of male productivity over female productivity. These two processes are closely connected. The ideologues of the witchhunt again and again denounced female nature as sinful ('sin' is synonymous with 'nature'), as sexualy uncontrollable, insatiable, and ever ready to seduce the virtuous man. It is interesting to note that women were not yet seen as sexually passive or even as a-sexual beings, as was the case later in the 19th-20th centuries. on the contrary, their sexual activity was seen as a threat to virtuous man, i.e. the man who wants to control the purity of his offspring, the heirs to his property. Therefore, it was man's obligation to guarantee the chastity of his daughters and his wife. As she is 'nature', 'sin', she had to be permanently under his guardianship, she became a permanent minor.

only men are capable of becoming adults in the true sense. To control their own women's sexuality the men were advised to resort to beatings and other violent devices (Bauer 1917). But all direct and ideological attacks on the sinful nature of women also served the purpose of robbing women of their autonomy over other economically-productive functions and of establishing male hegemony in most economic and non-economic spheres.

Sexual autonomy is closely connected with economic autonomy. The case of the professionalisation of male doctors, who arove out the denounced women healers and midwives as witches, is the best documentation of this onslaught on female productive activity. The new capitalist class rose on the subjugation of women (Rowbotham 1974). 
At the end of this 'civilizing process' we have the women who are disciplined enough to work as housewives for a man, or as wage labourers for a capitalist, or as both. They have learned to turn the actual violence that was used towards them by others through the centuries against themselves, and to internalize it - they defined it as 'love', the necessary ideological mystification of their own self-repression (Bock 1977). The institutional and ideological props necessary to maintain this self-repression were provided by the church, the state and, above all, by the family. Women were confined to this institution by the organisation of the labour process (division of household from workplace), by law, and by their economic dependence on the man as the so-called 'breadwinner'.

It would be an illusion, however, to think that the full development of capitalism would cause the barbarious features of its bloody beginnings to disappear, and that fully developed capitalist production relations would mean the end of the social paradigm of man-the-hunter/ warrior and the transformation of extra-economic coercion into economic coercion. 13

on the contrary, for the maintenance of an asymmetric exploitative division of labour on a national and international plane (the two are interlinked), fullfledged capitalism needs an ever-expanding state machinery of repression and a frightening concentration of means of destruction and coercion. None of the capitalist states has done away with the police or the military; they are, as among the hunters, warriors and warrior-nomads, still the most 'productive' sectors, because through the monopoly of now legalised violence, these states are able to curb effectively any rebellion among the workers within their orbit and also to force subsistence producers and whole peripheral areas to produce for a globally interlinked accumulation process. Though the exploitation for profit of human labour on a world scale has taken mainly the 
'rational' form of unequal exchange, the maintenance of the unequal relationship is guaranteed everywhere by means of direct coercion, by arms.

To summarize, the various forms of asymmetric, hierarchical divisions of labour which developed throughout history, upto the stage where the whole world is now structured into one system of unequal division of labour under the dictates of capital accumulation, are based on the social paradigm of the predatory hunter/warrior, who, without producing himself, is able by means of arms to appropriate and subordinate other producers, their productive forces and their products.

This extractive, non-reciprocal exploitative objective relationship to nature, first established between men and women, and men and nature, has remained the model for all other male modes of production, including capitalism, which has developed it to its most sophisticated and most generalised form. ${ }^{14}$ The characteristic of this model is that those who control the production process and the products are themselves not producers but appropriators. Their so-called productivity presupposes the existence and the subjection of other, and in the last analysis, female producers. As Wallerstein puts it: ... crudely, those who breed manpower sustain those who grow food who sustain those who grow other raw materials who sustain those involved in industrial production (Wallerstein 1977: 86). What wallerstein forgets to mention, is that all those sustain the non-producers who control this whole process in the last analysis by means of arms. Because at the heart of this paradigm lies the fact that non-producers appropriate and consume (or invest) what others have produced. Man-the-hunter is basically a parasite, not a producer. 
NOTES

1. This article is the result of a long collective process of reflection among women in the years 1975-1977, when I conducted courses on the history of the women's. movement at Frankfurt University Many of the ideas discussed here emerged in a course on Work and sexuality in Matristic societies! The thesis of one of my students, Roswitha Leukert, on 'Female sensuality' (1976) helped to clarify many of our ideas. I want to thank her and a11 the women who took part in those discussions. The present article was first given as a paper at the Conference on Underdevelopment and subsistence Reproduction, at the University of Bielefeld in 1979. A. German version was published in: Beiträge zur Feministischen Theorie und Praxis, No.3, 1980

2. The term 'exploitation is used here in the sense that a more or less permanent separation and hierarchisation has taken place between producers and consumers. The original situation in an egalitarian community, i.e that in which those who produce something are also - in an intergenerational sense - its consumers, has been disrupted. Exploitative social relations exist when non-producers are able to appropriate and consume (or invest) products and services of actual producers (see A Sohn-Rethel 1978; Rosa Luxemburg 1925).

3. Recent research on women workers in the Free Trade Zones in Southeast Asia and Latin America reveals that multinational corporations not only use and re-inforce existing patriarchal institutions, but also use modern sexist advertising to manipulate their mostly female labour force in Malaysia, South Korea, the Philippines, Singapore, Mexico, Haiti (Grossmann 1979, Pearson/EIson 1978, Lenz 1980). In the unorganised rural and urban sectors the housewife-ideology is used to transform pauperized peasant women into a totally atomized labour 
force in export-oriented household industries (Mies 1980).

4. 'Appropriation of Nature' (Aneignung der Natur) has a double meaning in German, and this ambiguity can also be found in the way Marx uses the expression. On the one hand he uses it in the sense of: 'making nature our own, to humanize nature'. In his earlier writings the formulation 'appropriation of nature' is used in this sense. On the other hand, it defines a relationship of dominance between Man and Nature. This is the case in Capital, in which Marx has reduced the broader definition to mean 'dominance over, control over, mastership over nature'. As we shall see, such an interpretation of this formulation proves problematic for women.

5. This sexism prevails in many languages. They cannot, like English, French and all Romanic languages, differentiate between 'man' (male being) and 'man' (human being). In the German language this difference can still be expressed: Mann is the male, Mensch the human being, though Mensch has also assumed a male connotation.

6. With Bornemann I use the term 'matristic' rather than 'matriarchal', because the latter implies that mothers were able to establish a political system of dominance. But not even in matrilineal and matrilocal societies did women establish such lasting political dominance systems (Bornemann 1975).

7. The Indian mother-godesses (Kali, Durga, etc.) are all embodiments of this active and practical principle, whereas many of the male Gods are passive, comtemplative and ascetic.

8. For a discussion of the relationship between a certain concept of nature and the appropriation of female bodies see also Colette Guillaumin, 1978.

9. A comparison of the terminology used in population research today with that of an earlier period would be 
very revealing. Up to the 1930 s the production of new life was still conceptualised as 'procreation', i.e. still had an active, creative connotation. But today, generative productivity is conceptualised in passive, biologistic, behavioristic and mechanistic terms such as 'fertility', 'biological reproduction', 'generative behaviour'. This definition of human generative productivity as passive fertility is a necessary ideological mystification for those who want to gain control over this last area of human autonomy.

10. This is not surprising as May uses the concept 'fertility' in the same sense as do most population. researchers and family planners, namely, as the result of unconscious, physiological behaviour.

11. For a further discussion of the seed-and-field analogy in ancient Indian literature, see also Maria Mies 1973, 1980; Leela Dube 1978.

12. See for instance Kathleen Gough: 'The Origin of the Family' in Rayna Reiter (ed.), Toward an Anthropology of Women.

13. At the present moment in history we can no longer share the opinion of the earlier Marxists, including Rosa Luxemburg, that warfare and violence were necessary as methods to solve conflicts of interest as long as the productive forces had not reached their highest development, as long as human beings had not achieved total contral and dominance over nature (cf. Rosa Luxemburg 1925: 155-156). Our problem is that this definition of 'development of productive forces' implies violence and warfare against nature and human beings.

14. At this point it would be appropriate to extend our analysis to the sexual division of labour under socialism. But this would require a much broader analysis. From what can be gathered from information about the status of women in socialist countries we can only conclude that 
the division of labour by sex is based on the same social paradigm as in the capitalist countries. One of the reasons for this may be that the concept of the 'development of productive forces' and man's relation to nature has been, the same as under capitalism, namely, man's lordship over nature, which implies his lordship over women. 
LITERATURE

ARDREY, Robert (1966): The Territorial Imperative (Atheneum, New York) :.

New York).

(1976): The Hunting Bypothesis (Atheneum,

BAUER, Max (1917): Deutscher Erauenspiegel München (Berlin).

BAZIN, Jean (1975): 'Guerre et Servitude à Segou', in: Meillassoux (ed.): L'esclavage dans l'Afrique precoloniale (Maspéro, Paris).

BECKER, Bovenschen,. Brackert et al (1977): Aus der 2eit der Verzweiflung: Zur Genese und Akutalität des Hexenbizdes, (e.s. Frankfurt).

BLOCH, Marc: Cambridge Economic Bistory of Europe I.

BOCK, Gisela (1977): 'Arbeit aus Iiebe - Liebe als Arbeit: Die Entstehung der Frauenarbeit im Kapitalismus' in: Frauen und Wissenschaft. Beiträge zur Berliner Sommeruniversität (Courage Verlag, Berlin).

BONTE, Pierre (1975): 'Esclavage et Relations de dépendence chez les Touaregs Kel Gress', in: Meillassoux (ed.): L'esclavage dans l'Afrique précoloniale (Maspéro, Paris).

BORNEMANN, Ernest (1975): Das Patriarchat (Fischer, Frankfurt).

BOSERUP, Esther (1970): Women's Role in Economic Development (st Martins Press, New York).

BRIFFAULT, Robert (1952): The Mothers (London).

BROWN, Judith (1970): 'Economic Organisation and the Position of Women among the Iroquois', in: Ethnohistory, No.17.

CHATTOPADHYAYA, Debiprasad (1973): Lokayata, A Study in Ancient Indian Materialism (New Delhi).

CHILDE, Gordon (1976): What Bappened in History (Penguin, London) .

DROSS, Annemarie (1978): Die erste Walpurgisnacht, Hexenverfolgung in Deutschland (Hauser, Wuppertal).

DUBE, Leela (1978): The Seed and the Field: Symbolism of Human Reproduction in India' (Paper read at the $\mathrm{Xth}$ International Conference of Anthropological Sciences, New Delhi). 
EHRENFELS, O.R. (1941): Mother-Right in India (Hyderabad).

ELIAS, Norbert (1978): Der Prozess der zivilisation (Suhrkamp, Frankfurt; English: The Civilising Process).

ENGELS, Frederic (1973): Origin of the Family, Private Property and the State (International publishers, New York).

FISHER, Elizabeth (1979): Women's Creation (Anchor Press, Doubleday, Garden (ity, New York).

FROBEL, T., KREYE, J., HEINRICHS, O. (1977): Die. neue internationale Arbeitsteilung, Strukturelle Arbeitslosigkeit in den Industrieländern und die Industrialisierung der Entwickliungsländer rororo aktuell (Reinbek).

GOODALE, Jane (1971): Tiwi Wives (Seattle and London, University of Washington Press).

GOUGH, Kathleen (1975): The Origin of the Family, in: Toward an Anthropology of Women, ed. R. Reiter.

GROSSMANN, Rachel (1979): Women's Place in the Integrated Circuit", in: South-East-Asia Chronicte, "SRC Issue No. 66 .

GUILLAUMIN, Colette (1978): 'Pratique du pouvoir et idé de Nature'. I. 'L'appropriation des femmes'; II. 'Le discours de la nature, in: Questions Feministes' (2 Fevrier, 3 Mai)?

HAMMES, Manfred (1977): Hexenwahn und Hexenprozesse (Fischer Taschenbuch, Frankfurt).

HERITIER, Francoise (1975): 'Des cauris et des hommes: production d'esclaves et accumulation de cauris chez les samos (Haute-Volta)', in: Meillassoux: $L^{\prime}$ esclavage dans l'Afrique pre-coloniaze.

HONEGGER, Claudia (ed.) (1978): Die Hexen der Neuzeit (e.s. Frankfurt).

KARVE, Iravati (1965): Kinship Organisation in India (Asia Publishing House, Bombay).

LEACOCK, Eleanor (1978): 'Women's status in Egalitarian Society: Implications for Social Evolution', in: Current Anthropology, Vol.19, No.2,

LEE, Richard Borshay (1980): The ! Kung san: Men, fomen and Work in a Foraging Society (Cambridge University Press, London, New York, New Rochelle, Melbourne, Sydney) . 
IENz, Ilse (1980): 'From the Farm to the Global Assembly Iine, The Situation of Women Workers in the Free production Zones in Malaysia!

(Paper read at ISS).

LEUKERT, Roswitha (1976): Weibliche Sinnlichkeit (unpublished thesis, University of Frankfurt).

LORENZ, Konrad (1963): Das sogenannte Böse (Wien; English translation: On Aggression).

MARTIN \& VOORHIES (1975): Female of the species (Columbia University Press, New York \& London):

MARX, Karl (1974): Kapital I (Lamrence \& Wishart, London).

MARX, Karl \& Friedrich ENGELS (1970): The German Ideology (ed. C.J. Arthur; New York).

MEILIASSoux, Claude (1974): Femmes, Greniers et Capitaux (Paris).

MIES, Maria (1973): Indische Frauen wwischen Patriarchat und Chancengleichieit (Anton Hain, Meisenheim/Glan).

(1980): English version: Indian Women and Patriarchy (Concept publishers, Delhi).

O'FAOLAIN, J.L., L. MARTINES (19.73): Not in God's Image: Women in History from the Greeks to the Victorians (Harper Torch Books, New York).

PEARSON, Ruth \& Diana ELSON (1977): 'The Internationalisation of Capital and its implications for women in the Third World' (paper, sussex).

REED, Evelyn (1975) : Woman's Evolution, From Matriarahal clan to Patriarchal Family: (New York).

REITER, Rayna (1977): 'The Search for Origins', in: Critique of Anthropology Women's Issue, $9 \& 10, \mathrm{Vol} .3$.

ROWBOTHAM, Sheila (1974): Bidden from Bistoxy (Pluto Press, London) (Penguin, London).

SLOCUM, Sally (1975): 'Woman the Gatherer', in: Toward an Anthropology of Women (ed. R. Reiter; Monthly Review Press, New York).

SOHN-RETHEL, Alfred (1978): 'Zur kritischen Liquidierung des Apriorismus', in Sohn-Rethel: Warenform und Denkform (e.s. Frankfurt). (e.s. Frankfurt).

(1970): Geistige und körpertiche Arbeit 
THOMSON, George (1965): Studies in Ancient Greek society: The Prehistorie Aegean (Citadel Press, New York).

TIGER, Lionel (1970): Men in Groups (Vintage, New York). TIGER, Lionel and Robin FOX (1971): The Imperial Animal (Holt, Rinehart and Winston, New York).

TURNBULL, Colin, M. (1961): The Forest People: A study of the Pygmies of the Congo (Simon and schuster, New York).

WALLERSTEIN, Immanuel (1974): The Modern World system: Capitalist Agriculture and the origins of the European World Economy in the Sixteenth Century (Academic Press, New York, San Francisco, London). 
Recent titles in the Occasional Pápers series include:

J.B.W. Kultenbrouwer: 'Rural Transformation in China'

C.A.O. van Nieuwenhuljze: Social Development - Supplement or Corrective to Economic Development?'

A.J.M. van de Laar: 'The World Bank and The Poor'

Jacob songsore: 'Structural Crisis, Dependent Capitalist Development and Regional Inequality in Ghana'

J.B.W. Kuitenbrouwer: 'Some Reflections on the Uses of Science and Technology in Indonesta!

Rachel Kurian: 'Income Distribution, Poverty and Employment'

J.B.W. Kuitenbrouwer: 'A Farewell to Welfare'

R. Apthorpe \& D. Gasper: 'Public Policy Evaluation, MetaEvaluation and Essentialism: The Case of Rural Cooperatives'

C.A.O. van Nieuwenhuijze: 'On Social Development: The Social Welfare Approach'

Maria Mies: 'Towards a Methodology of Women's Studies'

Jan van Heemst: 'Some Issues in connection with the Improvement of the Social Accounting systems of Developing Countries'

Peter Peek: 'Urban Poverty, Migration and Land Reform in Ecuador'

Don Townsend: 'Economic Integration, Opportunity Structure and Migration in Papua New Guinea'

J.G.M. Hilhorst: 'On Unresolved Issues in Reglonal Development Thinking'

Gerrit Huizer: 'Peasant Participation in Latin America and its Obstacles: an overview of conflict-resolution strategies'

J.G.M. Hilhorst: 'Regional Planning in Peru 1968-77: Top-Down or Bottom-up?'

G. van Benthem van den Bergh: 'On the Dynamics of Development of Contemporary States: an approach to comparative politics' 